\title{
Parents Experience in Giving Sex Education to Adolescents in North Kuta
}

\author{
Ida Arimurti Sanjiwani ${ }^{1}$, I Gusti Ayu Pramitaresthi ${ }^{2}$ \\ School of Nursing \\ Medical Faculty, Udayana University \\ Denpasar, Bali \\ ida.arimurti@unud.ac.id \\ School of Nursing \\ Medical Faculty, Udayana University \\ Denpasar, Bali i
}

\begin{abstract}
Sexual education is an important think that parents can do to prevent free sex and it effects in adolescent. It is possible because family is the first place of education, but it appears to be inadequately practiced in Indonesia. This study aims to determine parent experience to provide sexual education in adolescents. We used a phenomenology interpretative approach in this study. We collected the data through in-depth interviews with ten parents. We found five themes: (1) good perception about sexual education, (2) sexual education delivered assisted by social media, (3) the topic is free sex, (4) difficult to start because of taboo and shame, (5) need support from health worker. The study reveals that sexual education is limited and need to be increased. It is essential that Indonesian parents become better informed and skilled, so that they may be involved in the sexual education of adolescent start from their family.
\end{abstract}

\section{Index Terms - sexual education, adolescent, parents experience}

\section{INTRODUCTION}

Adolescent is a beautiful development phase. Their population reached more than 1.8 billion people from the total world population in 2010, While in Asia their population were 750 million [1,2]. They are filled with great curiosity, and usually begin to fall in love. [3,4]. Unhealthy dating can lead teens to risky sexual behavior [5].

Excessive sexual behavior has various physical and psychological impacts on adolescents such as pregnancy, abortion, sexual transmitted infections, HIV/ AIDS [5,1]. UNFPA's survey record that were 7.3 million girls under 18 years old give birth each year, and majority (95\%) occur in developing countries. In 2014, WHO had recorded too, about 16 million adolescents had given birth in 15-20 years[6]. Adolescent pregnancy also made major contribution to maternal and infant mortality, teenage death, dropping out of school, loss of self-esteem, early to be a parent, and economic problems [5,1].

Parents have a major role in informal sexual education because they have more time together. Parents who live with their teenagers have the opportunity to communicate every day, so parents play an important role in the development of their teens [7]. Lack of parent's support to providing sexual and reproductive information will have an impact on the poor ability of adolescents in making decisions for their reproductive health [8].

Bali is part of a developing country with a total number of teenagers reaching more than 893,000 people or nearly $23.9 \%$ of the population $[9,10]$. The population of Bali has increased by 743,758 people over the past 10 years. Preliminary studies have shown that the population surge is also due to adolescent pregnancy. According to 2006 PKBI data that adolescents first engage in sexual activity at the age of 13 to 18 years, and $60 \%$ do not use contraceptives even it is known that $85 \%$ are done at home [9].

Kuta is one of the centers of tourism in Bali and has absorbed many global developments. Seeing the conditions that occur today, researchers are interested in knowing how the experience of parents giving sex education to their adolescents.

\section{METHOD AND PROCEDURES}

This research was a qualitative study with descriptive phenomenology design. It studies about the experience of parents providing sexual education in adolescents. The population and sample are parents who have adolescent, 
The inclusion criteria of parents with children aged 10 to 18 years, have communication experience and provide sexual education to adolescents, able to communicate well. Data was collected in March-June 2017 in the working area of the North Kuta Health Center.

The sampling technique was done by Purposive Sampling, Purposive sampling is the most frequent and appropriate method used in phenomenological research [11]. The number of respondents were 10 peoples. The Data collection in this study was carried out by using in-depth interviews and field notes. The interview lasts for approximately 60-90 minutes with open interviews and recording devices.

The data analysis process was carried out after each data collection was completed in each participant. Transcripts and field notes are analyzed together using selective analysis and focusing from VanManen (1977), transcripts are read repeatedly to determine keywords, and made code to form categories, sub themes, and themes. The ethics of this research are autonomy and respect for human dignity, confidentiality, benefit, justice, protection from discomfort and harm. This research has been through ethical testing from the Sanglah General Hospital Denpasar ethics committee.

\section{RESULT AND ANALYSIS}

There were ten parents participated in this study. Their ages vary from 38 to 50 years. All participants live in North Kuta. Participant education background are 3 graduates from high school, 2 graduates from diploma 3, 3 graduates from bachelor degree, and 2 graduates from master degree. They work as housewives, private companies, entrepreneurs, farmers, and civil servants.

The results of the thematic analysis in this study are all participants have told all their expressions about experiences in providing sexual education to adolescents. There are five themes from this study.

(1) Good perception about sexual education.

What do you think about sexual education? That question began my interview with each participant in this study. The interviews showed that all participants considered sexual education to be important. Example of Participant's opinion which tells that sexual education really needs to be given to the community especially their children.

"Hmmm... Sexual education must be taught, especially this time. So everyone should understand that to be able to look after themselves" $(P 1)$.

"Ooo ... Sexual education is very good ... It should be increased dissemination of information because it is very important at this time." (P2)

"... yes, sexual education needs to be delivered and it is important, especially for young people, so that we don't get caught up in knowing the effects ..." (P4)
(2) Sexual education delivered assisted by social media

Participants reported that they provide sexual education directly or indirectly. It's seems easy but difficult. All participants admitted that they were helped by current technology, especially social media.

"I have conveyed sexual education to my child and it is even easier now because of the presence of hand phones and social media, ... so it's easy to explain" (P3)

"I usually tell children immediately if there are incidents caused by free sex when there is a news on social media hand phone" (P6)

\section{(3) Topic are free sex}

All participants said they told their childrens about free sex. Free sex is considered as a source of problems that will come if a teenager does not know the consequences for their future. They strengthen understanding of both their sons and daughters.

"I had told my daughter to always look after yourself, may you have a boyfriend but please don't do free sex or you will have bed future " (P7)

"I have a son. I said that if you fall in love with a girl, be careful ... it's ok you have dating properly, do it right, do not let you be affected by free sex" (P5)

(4) Difficult to start because of taboo and shame

The participants said it was difficult to start because they considered sex is taboo. At first they fill to be shame if they said the word of sex.

"This is like this ... I feel embarrassed when I start to say the word sex to my child, because it sounds taboo ... (P9).

(5) Need Support from health worker.

All participants said that they some need help from health workers. They hope it can help strengthen knowledge about sexual reproduction for adolescents. Like the statement from the following participants

"I really hope that health workers also help me teach about sex education, with more appropriate theories and more creative so young people are interested" (P10)

\section{DISCUSSION}

Good perception about sexual education. it is in line with studies before, that sexual education can reduce misinformation. Other study also states that through sexual education can help control adolescent boys and girls in assessing their sexual behavior and increase their understanding [12]. Parents who live with their teenagers have the opportunity to communicate every day, so parents also play an important role in the development of their children [7]. Previous study found that the implementation of communication between parents and adolescents is still 
rarely and limited $[13,14]$.

In this study it was found that sexual education was carried out by mothers and fathers but tended to be more often done between mothers with daughters and fathers with sons. This result is also proven by other studies that gender can be a determinant of the frequency of implementation of communication and sexual education between parents and children [15].

Sexual education is assisted by social media. There are great challenges in creating constant communication between adolescents and parents in discussing the issue of sexuality, moral cultivation by using an interesting methods and ways [16]. Adolescent expect have caring parents, willing to spend time together, want to listen to the intentions of teens with empathy, affection and positive feelings, respect and acceptance of parents, and give trust to adolescents [9].

It is about free sex. Study before said that sexual education content need to be review so we can understand of adolescent's need [17]. Indonesian government has published a program that helps families with teenagers through in 2009 which is expected to be a true source of information. Research before suggests sexual communication by parents to adolescents is still limited to physical changes in puberty, even parents who live in village had less information about sexuality [14].

There is shame and taboo. Many parents were uncomfortable in giving sexual education and even they tend to save the topic of conversation because sexual abuse is taboo [13]. Lack of information is one of the factors causing sexual behavior in adolescents in addition to being caused by hormones, late marriage, taboo, and promiscuity [15]. Similar studies also say it is taboo, so it is hoped that government norms and programs should be able to help change the current situation [18]. Parent tends to avoid sexual talk by reason of lack of knowledge about sex [19].

Help from health workers. It is consistent with the study before that there is still a need for further study of the source of information and its contents so that it can understand the needs of adolescents [18]. Other study states that health workers can help with the implementation of sexual education for adolescents must be continually updated with a more complete and interesting [20].

\section{CONCLUSION}

It can be concluded that the experience of parents in sexual education in adolescents is still lack and needs to be improved. Increasing awareness of the importance of sexual information and support of health facilities and teams are expected to improve the quality of education starting from the family. It is hoped that further studies can examine the experiences of adolescents in receiving sexual education.

\section{ACKNOWLEDGMENT}

The authors thank any parties that support this study, especially to Udayana University. We are also very grateful to all of participant for allowing to carry out this project.

\section{REFERENCES}

[1] UNFPA The future is a girl at age 10. "Why we need to invest adolescent and young girl to reduce maternal mortality." Avaliable from:

http://www.who.int/pmnch/about/governance/partnersforum/youth_u nfpa.pdf.2014

[2] Unicef. "Progres for Children. A report card on adolescent." Avaliable from: http://www.unicef.org/publications/files/Progress_for_Children__No._10_EN_04232012.pdf. 2012.

[3] Fogel, C.I \& Woods,N.F. "Women's Health Care In Advanced Practice Nursing." New New York: Springer Publishing Company. 2008.

[4] Sarwono, Sarlito.W "Psikologi Remaja" Edisi Revisi. Jakarta : Rajawali Pers. 2011.

[5] Tharp, A. T., Carter, M., Fasula, A. M., Hatfield-Timajchy, K., Jayne, P. E., Latzman, N. E., \& Kinsey, J. "Advancing Adolescent Sexual and Reproductive Health by Promoting Healthy Relationships” Journal Of Women's Health 2013., 22(11), 911-914. doi:10.1089/jwh.2013.4534. 2013.

[6] WHO.Pregnancy.availablefrom.ahttp://www.who.int/mediacentre/fac tsheets/fs364/en/2014.

[7] Jerman, P., \& Constantine, N. A. "Demographic and psychological predictors of PAC about sex: a representative state-wide analysis" Journal of Youth Adolescence, 2010. 39, 1164-1174.2010.

[8] Wyckoff, et al "Patterns of sexuality communication between preadolescents and their mother and fathrts" J Child Fam Stud 2008.17;649-662. Doi. 10.1007/s10826-007-9179-5.2008.

[9] BKKBN Bali. "Remaja kehilangan kualitas generasi muda" 2015 Available http://bali.bkkbn.go.id/ViewBerita.aspx?BeritaID=3584. 2015

[10] Rimbawan, D. "Kaum Muda Bali: Harapan VS Kenyataan". PIRAMIDA 2013. Vol/ IX. No. 1: 24- 33. ISSN: 1907-3275

[11] Afiyanti, Y, Rachmawati, I.N. "Metodologi Penelitian Kualitatif dalam Riset Keperawatan” Depok: Rajawali Pers. 2014.

[12] Eisenberg ME, Madsen N, Oliphant JA, Sieving RE. "Barriers to providing the sexuality education that teachers believe students need". J Sch Health. 2013; 83: 335-342. 2013.

[13] Ayalew, M., Mengistie, B., \& Semahegn, A. "Adolescent - parent communication on sexual and reproductive health issues among high school students in dire dawa". eastern ethiopia: A cross sectional study. Reproductive Health, 11, 77. doi:http://dx.doi.org/10.1186/1742-4755-11-77. 2014

[14] Wamoyi. J, Fenwick,A., Urassa,M., Zaba, B. Stones, W. "RPeaserarechnt-child communication about sexual and reproductive health in rural Tanzania: Implications for young people's sexual health interventions". Reproductive Health 2010, 7:6. Reyrived from: http://www.reproductive-health-journal.com/content/7/1/6. 2010.

[15] Zhang, L., Li, X., Shah, I.H., Baldwin, W., \& Stanton, B. "Parentadolescent sex communication in China. The European Journal of Contraception and Reproductive Health Care" 2007. 12(2),138-147

[16] Rouvier, M, Camperob, L, Walker, D \& Caballero, M. "Factors that influence communication about sexuality between parents and adolescents in the cultural context of Mexican families" Sex Education. Vol. 11, No. 2,. DOI: 10.1080/14681811.2011.558425. 2011.

[17] Hall, K. S., Moreau, C., \& Trussell, J. "Associations Between Sexual and Reproductive Health Communication and Health Service Use Among U.S. Adolescent Women”. Perspectives On Sexual \& Reproductive Health, 44(1), 6-12. doi:10.1363/4400612. 2012.

[18] Tesso,D. Fantahun,M. Enquselassie, F. "Parent-young people communication about sexual and reproductive health in E/Wollega zone, West Ethiopia: Implications for interventions. Reproductive Health". 2012, 9:13. http://www.reproductive-healthjournal.com/content/9/1/13.2012. 
Journal of A Sustainable Global South, p-ISSN: 2579-6062

[19] Mahajan, P., \& Sharma, N. "Parents' attitude towards imparting sex education to their adolescent girls". Anthropologist, 7(3), 197-199. 2005.

[20] Eisenberg ME, Madsen N, Oliphant JA, Sieving RE. "Barriers to providing the sexuality education that teachers believe students need". J Sch Health. 2013; 83: 335-342. 2013. 